\title{
NEWS AND NOTES
}

\section{CANADIAN COUNCIL OF \\ PROFESSIONAL ENGINEERS AND SCIENTISTS}

$\mathrm{D}$ R. F. S. HOWES, Associate Professor of Electrical Engineering at McGill University, was re-elected Chairman of the Canadian Council of Professional Engineers and Scientists for the current year at a regular meeting held yesterday at the Chateau Laurier in Ottawa. Mr. W. J. Gilson, President, Eastern Power Devices Limited, Toronto, was, at the same time, re-elected Vice-Chairman of the Council.

Advice received from the Minister of Labour that the Bureau of Technical Personnel is being continued as an agency of the Department indicates a move which the Council is convinced will receive the enthusiastic support of technical persons and their employers. The Council noted, however, with regret, that the regional offices of the Bureau are to be closed as it believes that the withdrawal of experienced and competent staff from these centres will result in major curtailment in employment service available to both engineers and scientists, and their employers.

The Council received a report from its Salary Survey Committee indicating the type of information on the subject of salaries already available at the Bureau of Technical Personnel and instructed the Committee to explore the matter further and to advise the next meeting as to means of making fuller use of such information, in the best interests of employee engineers and scientists.

The Council considers it to be extremely desirable that at the earliest possible moment the Dominion Government should set up a National Commission, as envisaged in the pertinent article of the constitution of UNESCO. Early action in this regard will enable this Commission to be available for consultation by the Government well in advance of the next general meeting of UNESCO which is to take place in Mexico City next autumn. Considerable disappointment was expressed at the regular meeting of the Canadian Council of Professional Engineers and Scientists held on May 5 in Ottawa at the lack of progress of the Government in completion of organization of Canadian participation in UNESCO. Realizing that the next meeting of UNESCO is now planned for Mexico City later this year, the Council had been hopeful that decisions would have been taken and announcements made by the Dominion Government before now. $U_{p}$ to date, press comment has contained very little reference to the scientific aspects of UNESCO operations. The Council believes that science will play a major part in the future achievements of UNESCO and that the Government should carefully select such scientific representation as will adequately present the role of science in Canadian world economy.

The Council received a report of the recent meeting held to discuss the establishment of a Parliamentary and Scientific Committee in Canada. 
A. E. MacRae was selected to serve on the Interim Committee now considering possible action. Co-operating organizations have unanimously approved the principle, and the Council has undertaken to give full support to the establishment of a Parliamentary and Scientific Committee. It feels that much good can be derived from association with Parliamentarians in discussion of scientific matters and that the information provided by pro. fessional engineering and scientific bodies will be of significant assistance to them in consideration of future legislation.

The question of a National Employment Service for technical persons was again the subject of discussion and specific recommendations will be made to the Minister of Labour in this connection. Other suggestions will be put forward regarding the maintenance by the Bureau of Technical Personnel of the National Roster of professional engineers and scientists. It is realized by the Council that proper maintenance of this Roster will provide the Bureau with all information necessary for tabulation at regular in. tervals of the types of activities in which technical persons are engaged, and of average salaries of different age groups and professional classifications.

\section{NEW DEAN AT TORONTO}

President Sidney Smith announces that Dean Gordon G. Cosens of the Faculty of Forestry has resigned his position, his resignation being effective June 30, 1947. He has accepted an important post with the Kimberly. Clark Corporation of Nennah, Wisconsin, with headquarters in Toronto, and will continue next session to deliver lectures on Forest Utilization to the students of the Third Year in Forestry. Professor Cosens joined the staff of the Faculty of Forestry in 1934 and was appointed Dean in July, 1941. In those six years he has made a significant contribution to the development of the Faculty over which he presided and to the University as a whole. It is with much regret that his colleagues and his students see him leave a position which he has adorned.

The new Dean of the Faculty of Forestry is to be Professor John William Bernard Sisam, who obtained the degree of Bachelor of Science in Forestry at the University of New Brunswick and the degree of Master of Forestry from Yale University, and who has been Associate Professor for two years in the Faculty of Forestry in the University of Toronto. Professor Sisam, who is 40 years of age, was born in Springhill, Nova Scotia, the son of an Anglican clergyman who came to Canada from England. He has had an extensive experience, having been Deputy Director of the Imperial Forestry Bureau at Oxford for six years, after some years spent in the Dominion Forest Service. He is the author of several standard articles and bulletins.

Announcement by W. J. DUNLOP, University of Toronto, April 21, 1947. 